\title{
The rise of the Arctic: Intergenerational personal perspectives
}

\author{
This article belongs to Ambio's 50th Anniversary Collection. Theme: Climate change \\ impacts
}

\author{
Terry V. Callaghan, Margareta Johansson
}

Published online: 1 March 2021

\section{CHANGING PARADIGMS}

Within the past four decades, the significance of the Arctic has risen significantly within global perspectives. When Terry Callaghan started to work in the Arctic more than half a century ago, the Arctic Region and much of the research there was esoteric with few people and few countries interested and involved in Arctic issues and research. In fact, from the late 1940s until the collapse of the Soviet Union in 1991, the Cold War had ensured that the Arctic was a strategic zone and a region of potential military confrontation between the world's two superpowers (Nutall and Callaghan 2019). Terrestrial ecological research emphasis was on recording the plant communities of the Arctic, measuring rates of productivity and decomposition, and understanding how the plants and animals there were adapted to harsh, cold environmental conditions. There was little or no concept of change and the perception was that the Arctic was more or less stable during this period. There was some networking between nations and the International Biological Program Tundra Biome Project (1964-74: Bliss et al. 1981) included East-West collaboration. However, in those days, the voices of the Indigenous Peoples were not heard in Arctic Science or in general.

The career, so far, of Margareta Johansson has experienced a shift in almost all of the above paradigms. Current research focuses on change: changes in the Arctic climate, its landscapes, its ecosystems, societies and its geopolitics and in all topics, research has proliferated. Now, we are less concerned with how plants and animals survive in harsh conditions and we are more concerned with how they will cope with mild, snow-free periods in winter and summer warming - up to $38{ }^{\circ} \mathrm{C}$ in Siberia in June 2020! (WMO 2020). At the same time, the voices of Indigenous
Peoples are heard more and more and they are involved in research projects and co-production of knowledge. The Arctic is no longer esoteric. Many countries far from the Arctic have become stakeholders, the general public have become aware of the sensitivity of the Arctic to change and the threats to iconic species and ecosystems. Most importantly there is recognition and concern that environmental changes in the Arctic will impact the environment and lives of people around the world.

How we did our research and shared information have also changed dramatically. Terry Callaghan carried out research without computers-and even without electronic calculators-and bibliographic searches were carried out in the book shelves of university libraries. When volumes were not in a library, they were requested from other libraries by inter-library loans and the postal service, a process taking several days. In complete contrast, Margareta Johansson works in the digital age with all the benefits of the Internet and increasing opportunities of technical and technological development for field work and data analysis and data sharing but with the challenge of unlimited data and information. What caused such major paradigm shifts?

\section{THE DEVELOPMENT OF INTERNATIONAL ARCTIC SCIENCE}

In October 1987, Soviet Union President Mikhail Gorbachev gave a speech in Murmansk calling for the Arctic to become a zone of peace. Almost immediately, there was an international response: a Norwegian 1960s strategy for the former coal-mining town of Ny Ålesund on Svalbard to become an international centre for research was rapidly implemented with new national research stations and 
programs constructed, a Finnish initiative in 1989 led to the Arctic Environmental Protection Strategy (AEPS) of 1991, and the circumpolar North became a region for new forms of international intergovernmental cooperation (Nutall and Callaghan 2019). At the same time, there was a new recognition that the climate of the Arctic was changing and early studies began to assess the impacts that these-at that time "possible" changes-could have on the ecology of the Arctic (e.g. Chapin et al. 1991; Callaghan et al. 1992). Shortly afterwards, it was recognised that changes in Arctic ecosystems could accelerate warming by providing positive feedbacks to the climate system from the release of the greenhouse gas $\mathrm{CO}_{2}$ (Oechel et al. 1993).

Soon, scientists and Indigenous Peoples started to notice changes in contaminants and their impacts, changes in biodiversity and the early warning signs of climate change impacts. The international community responded by forming the International Arctic Science Committee (IASC) in 1990 (IASC 2015). One of the first (1995) working groups "Feedbacks and Arctic Terrestrial Ecosystems: FATE" was led by Terry Callaghan and focussed on conceptualising the impacts that a changing Arctic environment could have over wider geographical areas. At the same time, some of the Arctic's Indigenous Peoples gained various extents of self-governance and by the early 1990s, it was clear that the Arctic was not remote and isolated but instead was interconnected with the rest of the world: it both experienced environmental impacts from outside and had the possibility to affect global climate. In September 1996, the inauguration of the Arctic Council signalled the establishment of an internationally recognised region of considerable importance that consisted of Government Ministers of the eight Arctic Countries (Canada, Denmark/Greenland, Finland, Iceland, Norway, Russia, Sweden and the United States of America) and Indigenous Peoples' organisations as permanent participants. Currently, 13 countries have "Observer status" while more countries are seeking such involvement.

\section{DOCUMENTING ARCTIC CLIMATE CHANGE AND ITS WIDER IMPLICATIONS}

The Arctic Council established various working groups of which the Arctic Monitoring and Assessment Programme (AMAP) and Conservation of Biodiversity (CAFF) working groups played a leading role in assessing pollution and climate change and its impacts. Working together with IASC, they accomplished the world's first regional assessment of climate change and its impacts-the Arctic Climate Impact Assessment of 2005 (ACIA 2005) - a report written by more than 300 scientists working for four years to produce a 1020-page report. This ground-breaking assessment arguably provided the most substantial evidence of climate change for the Intergovernmental Panel on Climate Change Fourth Report of 2007 that led to the award of the Nobel Peace Prize. The reasons for the strength of the Arctic perspective were that warming in the Arctic was occurring at twice the rate of the global average and lack of intensive land-use changes led to the identification of cause-effect environmental changes clearly observed by scientists and Indigenous Peoples. In other regions of the world, feedbacks that amplified warming were less pronounced and climate change impacts were still only a theoretical possibility.

\section{COMMUNICATING SCIENTIFIC UNDERSTANDING GLOBALLY}

Terry Callaghan was the lead author of various chapters in the ACIA report and, together with a small team, ensured that ACIA results were incorporated into the IPCC 2007 Polar Regions Chapter (Anisimov et al. 2007). Margareta Johansson was a research assistant within the ACIA process. Together, they achieved inclusion of Indigenous Knowledge in the science assessment and a paper was soon published in Ambio on the importance of using both types of knowledge (Huntington et al. 2004). The ACIA was presented in two reports, the comprehensive study (ACIA 2005) and a relatively short popular science summary (ACIA 2004). However, the authors of the chapter on Arctic terrestrial ecosystems wanted to maximise global awareness of the issues and approached Ambio as an internationally highly regarded journal of the human environment. Ambio agreed to publish a special issue dedicated to this particular chapter of the ACIA (Callaghan 2004) and the first paper in this section (Callaghan et al. 2004) is one of the papers in that Special Issue. This publication in Ambio set an important precedent: soon afterwards, the ACIA freshwater chapter was published in Ambio (Wrona et al. 2006) and many subsequent assessments have been published there since.

Following the publication of the ACIA findings, it soon became clear that the speed of climate change and its impacts in the Arctic were faster than expected and there was particular concern about changes in the cryosphere (the frozen parts of the planet). Also, some aspects of the cryosphere such as snow dynamics had not been comprehensively assessed by ACIA. Consequently, AMAP in close cooperation with the International Arctic Science Committee (IASC), the World Climate Research Programme/Climate and Cryosphere (WCRP/CliC) Project and the International Arctic Social Sciences Association (IASSA) implemented a new assessment_- "Snow, water, Ice and Permafrost in the Arctic" - SWIPA—published as 
a report in 2011. Terry Callaghan was a lead author of the snow and permafrost chapters of the assessment and Margareta Johansson, a research assistant in the ACIA process, became a lead author too. The inclusion of Indigenous Knowledge in the ACIA now developed into the inclusion of an Indigenous lead author. Once again, some of the SWIPA chapters were published as a Special Issue of Ambio (Callaghan et al. 2011a, Guest Editors) and the second paper in this section is a chapter on "The changing face of Arctic snow cover: a synthesis of observed and projected changes" (Callaghan et al. 2011b).

\section{THE ARCTIC TODAY AND IN THE FUTURE}

Climate change impacts in the Arctic have led to better transport routes as sea ice recedes from coastlines, and greater accessibility to resources such as off-shore oil and gas. The awareness of such possibilities has generated economic interest from around the world but also environmentalists' concern, geopolitical tensions and increased militarisation of the Arctic. However, the Arctic Council and its activities seek to stimulate and preserve peace in the Arctic that can somehow reduce geopolitical tensions elsewhere. Added to this is the growing concept of "Science Diplomacy": the ACIA and SWIPA reports and the Ambio Special Issues based on them, united scientists from around the world. The ethos of collaboration exemplified by the two Ambio papers grew into increased networking: Terry Callaghan founded the INTERACT Network of research stations and co-founded the Siberian Environmental Change Network, while Margareta Johansson now coordinates INTERACT which networks 88 research stations in 16 countries and hosts over 15000 researchers from around the world each year. (INTERACT was based on the SCANNET network of North Atlantic Research Stations that was first described in an Ambio publication.) Transnational access, where researchers can apply to INTERACT for funding to undertake field work at a station not belonging to their own nation, has resulted in greater East-West collaboration and understanding of different cultures and perspectives. Such Science Diplomacy is being increasingly recognised by various embassies and the Arctic Council now has a Science Cooperation agreement.

The new world created by climate change will need new skills and a new generation of researchers working with Indigenous Peoples and other Arctic residents to mitigate the challenges and maximise opportunities. The ACIA and SWIPA processes, the Ambio papers presented here and associated networking, specifically included early career scientists to form the next generation of globally important assessors and communicators. Margareta Johansson has contributed to the Association of Polar Early Career
Scientists (APECS) and the Permafrost Young Researchers Network (PYRN), while Terry Callaghan is Patron of the Wicked Weather Watch Charity for primary school children.

\section{CONCLUSION}

The two papers presented here (Callaghan et al. 2004, 2011b) represent significant developments in international cooperation in science and also show how knowledge and experience have been handed down between generations of scientists and how indigenous voices have been included in Arctic science assessments. The role played by the ACIA and SWIPA assessments not only alerted the world to rapid and harmful climate change but it also provided a platform for highly successful international cooperation between science and Indigenous knowledge that have provided a continuing and expanding international diplomacy in science. They were also part of major international initiatives that arguably changed the world's awareness of the Arctic and climate change in general. The impacts of the ACIA and SWIPA assessments - and subsequent assessments - were maximised by publishing in Ambio, a truly multidisciplinary journal of the human environment with a global distribution.

\section{REFERENCES}

ACIA. 2004. Impacts of a Warming Arctic: Arctic Climate Impact Assessment. ACIA Overview report, 140. Cambridge: Cambridge University Press.

ACIA. 2005. Arctic Climate Impact Assessment. ACIA, 1020. Cambridge: Cambridge University Press.

Anisimov, O.A., D.G. Vaughan, T.V. Callaghan, C. Furgal, H. Marchant, T.D. Prowse, H. Vilhjálmsson, and J.E. Walsh. 2007. Polar regions (Arctic and Antarctic). In Climate Change: Impacts, Adaptation and Vulnerability. Contribution of Working Group II to the Fourth Assessment Report of the Intergovernmental Panel on Climate Change, ed. M.L. Parry, O.F. Canziani, J.P. Palutikof, C.E. Hanson, and P.J. van der Linden, 655-685. Cambridge: Cambridge University Press.

Bliss, L.C., O.W. Heal, and J.J. Moore (eds.). 1981. Tundra Ecosystems: A Comparative Analysis (International Biological Programme 25), 257-284. Cambridge: Cambridge University Press.

Callaghan, T.V., M. Sonesson, and L. Somme. 1992. Responses of Terrestrial Plants and Invertebrates to Environmental Change at High Latitudes. Philosophical Transactions Royal Society London B 338: 279-288.

Callaghan, T.V. (eds.). 2004. Climate Change and UV-B impacts on Arctic Tundra and Polar Desert Ecosystems, Special Issue. Ambio 33: 385-479.

Callaghan, T.V., L.O. Björn, Y. Chernov, T. Chapin, T.R. Christensen, B. Huntley, R.A. Ims, M. Johansson, et al. 2004. Climate Change and UV-B impacts on Arctic Tundra and Polar Desert 
Ecosystems: Biodiversity, Distributions and Adaptations of Arctic Species in the Context of Environmental Change. Special Issue. Ambio 33: 404-417. https://doi.org/10.1579/0044-744733.7.404.

Callaghan, T.V., M. Johansson, and T.D. Prowse (eds.). 2011a. Arctic Cryosphere-Changes and Effects (SWIPA) Ambio 40.

Callaghan, T.V., M. Johansson, R.D. Brown, P.Y. Groisman, N. Labba, V. Radionov, R.G. Barry, O.N. Bulygina, et al. 2011b. The Changing Face of Arctic Snow Cover: A Synthesis of Observed and Projected Changes. Ambio 40: 17-31. https://doi. org/10.1007/s13280-011-0212-y.

Chapin III, F.S., R.L. Jefferies, J.F. Reynolds, G.R. Shaver, and J. Svoboda (eds.). 1991. Arctic Ecosystems in a Changing Climate: An Ecophysiological Perspective, 469. Cambridge: Academic Press.

Huntington, H., T.V. Callaghan, S.H. Fox, and I. Krupnik. 2004. Matching Traditional and Scientific Observations to Detect Environmental Change: A Discussion on Arctic Terrestrial Ecosystems. Ambio Special Report 13: 18-23.

IASC. 2015. IASC after 25 years. Eds. O. Rogne, V. Rachold, L. Hacquebord, R. Correll. 128 pp. ISBN: 978-3-9813637-7-7.

Nutall, M., and T.V. Callaghan. 2019. The Arctic: Environment, People, Policy. Harwood Academic Publishers, Reading, Preface, Re-release of the 2000 volume UK, $647 \mathrm{pp}$.

Oechel, W.C., S.J. Hastings, G.L. Vourlitis, M. Jenkins, G. Riechers, and N. Grulke. 1993. Recent Change of arctic Tundra
Ecosystems from a Net Carbon Dioxide Sink to a Source. Nature 361: 520-523. https://doi.org/10.1038/361520a0.

WMO. 2020. World Meteorological Organization web site news 8 July, 2020: https://public.wmo.int/en/media/news/june-seesmore-global-heat-especially-arctic-siberia.

Wrona, F.J., T.D. Prowse, J.D. Reist, J.E. Hobbie, L.M.J. Levesque, and W.F. Vincent. 2006. Climate Impacts on Arctic Freshwater Ecosystems and Fisheries: Background, Rationale and Approach of the Arctic Climate Impact Assessment (ACIA). Ambio 35: 326-329. https://doi.org/10.1579/0044-7447(2006)35\%5b326: CIOAFE\%5d2.0.CO;2.

Publisher's Note Springer Nature remains neutral with regard to jurisdictional claims in published maps and institutional affiliations.

\section{Terry V. Callaghan $(\bowtie)$}

Address: Department of Animal and Plant Sciences, University of Sheffield, Western Bank, Sheffield S10 2TN, UK.

Address: Tomsk State University, Lenin Ave, 36, Tomsk, Tomsk Oblast, Russia 634050.

e-mail: terry_callaghan@btinternet.com

\section{Margareta Johansson}

Address: Department of Physical Geography and Ecosystem Science, Lund University, Sölvegatan 12, 22362 Lund, Sweden.

e-mail: margareta.johansson@nateko.lu.se 